IJCCS (Indonesian Journal of Computing and Cybernetics Systems)

Vol.13, No.3, July 2019, pp. 241 250

ISSN (print): 1978-1520, ISSN (online): 2460-7258

DOI: https://doi.org/10.22146/ijccs.46490

\title{
DSS for Selection of Coffee Plants against a Land Using ANP and Modification Of Profile Matching
}

\author{
Indra Pratistha*1, Retantyo Wardoyo ${ }^{2}$ \\ ${ }^{1}$ Master's Program of Computer Science, FMIPA UGM, Yogyakarta, Indonesia \\ ${ }^{2}$ Department of Computer Science and Electronics, FMIPA UGM, Yogyakarta, Indonesia \\ e-mail: ${ }^{* 1}$ indra.pratistha@mail.ugm.ac.id, ${ }^{2}$ rw@ugm.ac.id
}

\begin{abstract}
Abstrak
Berdasarkan data BPS pertumbuhan produksi tanaman perkebunan Provinsi NTB pada tahun 2011 hingga tahun 2016 tercatat mengalami penurunan rata-rata sebesar 3,3 ribu ton setiap tahunnya. Salah satunya terjadi pada tanaman kopi yaitu rata-rata sebesar 0,1 ribu ton, salah satunya disebabkan oleh kurangnya pengetahuan masyarakat dalam melakukan penanaman kopi secara tepat terhadap lahan yang dimiliki sehingga hal tersebut berdampak pada penggunaan lahan yang tidak sesuai dengan potensinya yang dimana akan mengakibatkan produktivitas menurun dan pengikisan kualitas lahan. Berdasarkan hasil diskusi bersama pakar perkebunan politeknik LPP pada penelitian ini karakteristik yang didapat terbagi atas data yang bersifat kualitatif yang terdiri dari drainase dan tekstur tanah dan data kuantitatif terdiri dari temperatur, curah hujan, kelembaban udara, elevasi, kedalaman efektif tanah, lereng, KTK tanah, kejenuhan basa, pH H2O, c organik, dan kandungan N. Hasil dari penerapan metode ANP dan profile matching yang dimodifikasi menunjukan bahwa kedua metode ini dapat memberikan rekomendasi tanaman kopi terhadap lahan di Kabupaten Lombok Timur, dari pengujian yang dilakukan terhadap hasil ranking dimana hasil antara data skala perbandingan berpasangan dari Pakar Politeknik LPP dan Dinas Pertanian Provinsi NTB menghasilkan 7 kecamatan yang cocok dan 1 kecamatan yang tidak cocok yaitu kecamatan Wanasaba.
\end{abstract}

Kata kunci-Tanaman, Lahan, SPK, ANP, Profile Matching

\begin{abstract}
Based on BPS data, the growth of plantation crop production in NTB Province in 2011 to 2016 was recorded to have decreased by an average of 3.3 thousand tons annually. One of them occurs in coffee plants, which is an average of 0.1 thousand tons, one of which is caused by a lack of knowledge of the community in planting coffee properly on land owned so that it affects land use which is not in accordance with its potential which will result in productivity decreases and erosion land quality. Based on the results of discussions with LPP polytechnic plantation experts in this study the characteristics obtained were divided into qualitative data consisting of drainage and texture and quantitative data consisting of temperature, rainfall, humidity, elevation, effective depth of soil, slope, soil KTK, base saturation, $\mathrm{pH} H 2 \mathrm{O}$, c organic, and $N$ content. The results of applying the ANP method and modified matching profile show that both of these methods can provide recommendations for coffee plants to land in East Lombok Regency, from tests conducted on ranking results where the results of pairwise comparison scale data from Pakistani Polytechnic LPP and the Agriculture Office of NTB Province produce 7 suitable sub-districts and 1 sub-district that is not suitable, namely Wanasaba sub-district.
\end{abstract}

Keywords-Plants, Land, DSS, ANP, Profile Matching

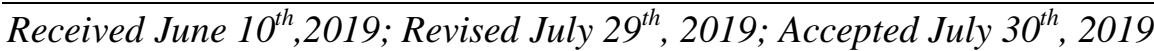




\section{INTRODUCTION}

Developments in the Agriculture and Mining Sector in Indonesia, especially in the plantation sector of the production sector, generally experienced a decline in growth. Based on the data at the Central Statistics Agency (BPS), the decline in production occurred in several plantation crops from 2011 to 2016, an average of 85.95 thousand tons. One of the declining rates of growth in plantation production occurred in West Nusa Tenggara Province.

Based on data from BPS, the growth of plantation crop production in West Nusa Tenggara Province in 2011 to 2016 was recorded to have decreased by an average of 3.3 thousand tons annually in the production of coconut (Cocos nicifera L.), coffee (Coffea) and tobacco (Nicotiana tabacum L.), one of them occurs in coffee plants, which is an average of 0.1 thousand tons per year. Based on the results of interviews with one of the parties from the Agriculture Office of West Nusa Tenggara Province (Dinas Pertanian Provinsi Nusa Tenggara Barat) that the decline in production was caused by several factors, one of which was caused by a lack of public interest in planting coffee properly for the land owned, so that it had an impact on inappropriate land use with its potential which will result in decreased productivity and erosion of land quality [1].

Based on data obtained through polytechnic plantation experts the characteristic LPP obtained is divided into qualitative and quantitative data where qualitative data is calculated using proximity values and quantitative data is calculated using linear interpolation functions through conformity classes because the characteristics of certain plants are specified for example soil $\mathrm{pH}$ at Arabica coffee plants namely $\geq 5,5$ to $\leq 6,6$. Several land characteristics generally have a relationship with each other [2]. LPP polytechnic experts say that there is dependency between criteria one with other criteria. For example, the temperature criterion affects the humidity where the lower the temperature the higher the humidity will be.

From the above problems, an analysis is carried out that can provide recommendations on the determination of coffee plantation crops on land in East Lombok Regency. This methodology is expected to be able to overcome the dependency problem among the criteria established by the LPP polytechnic plantation experts so that it is expected to increase the productivity value of coffee plantation crops in West Nusa Tenggara Province.

\section{METHODS}

\subsection{Decision Support System}

Decision Support Systems are interactive computer-based systems that can help make decisions by utilizing data and models to solve unstructured problems [3].

Decision Support System is a computer-based system that is interactive in helping decision makers by utilizing data and models to solve unstructured problems [4].

\subsection{Linear Interpolation}

Linear interpolation is one of the simplest methods to find a value in a graph that has 2 points connected in a straight line. [5] Linear form is created by drawing a straight line between two known meeting points, namely A and E. Furthermore, by drawing the known data lines, namely $x$ and $f(x)$, and then the relationship of two triangles, namely the corresponding triangle $\mathrm{ABC}$ and $\mathrm{ADE}$, where there is a relationship that can be seen in equation (1).

$$
\frac{B C}{A B}=\frac{D E}{A D}
$$

Figure 1 shows a chart of linear interpolation 


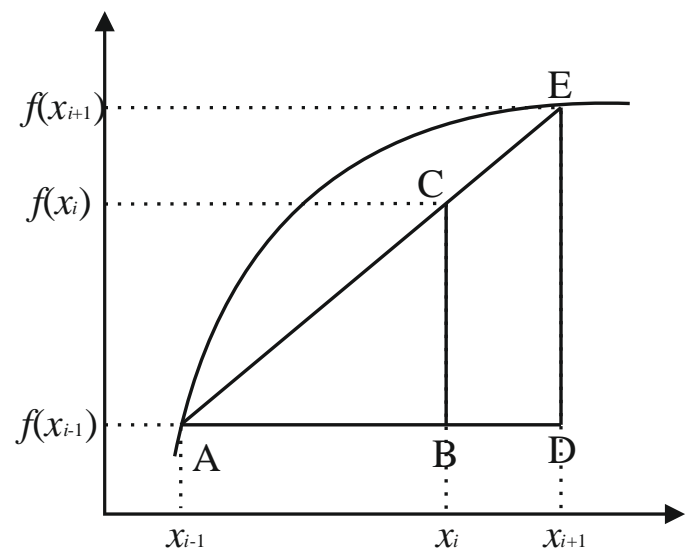

Figure 1 Linear interpolation

From equation (1), a new equation can be formed through Figure 1, and then equation (2) is obtained as follows:

$$
f\left(x_{i}\right)=f\left(x_{i-1}\right)+\frac{f\left(x_{i+1}^{x}\right)-f\left(x_{i-1}^{j}\right]}{x_{i+1}-x_{i-1}^{2}}\left(x_{i}-x_{i-1}\right)
$$

$f\left(x_{i}\right) \quad$ : the value on the $\mathrm{Y}$ axis against the value $x_{i}$ on the $\mathrm{X}$ axis is attempted to find.

$f\left(x_{i-1}\right) \quad$ : the value on the $\mathrm{Y}$ axis against the value $x_{i-1}$ on the $\mathrm{X}$ axis, the point position is to the left hand.

$f\left(x_{i+1}\right)$ : the value on the $\mathrm{Y}$ axis against the value $x_{i+1}$ on the $\mathrm{X}$ axis, the point position is to the right hand.

$x_{i-1} \quad$ : the point position is to the left on the $\mathrm{X}$ axis.

$x_{i+1} \quad$ : the point position is to the right hand on the $\mathrm{X}$ axis.

$x_{i} \quad$ : the point position searched is on the $\mathrm{X}$ axis.

\subsection{Pairwise Comparison}

The pairwise comparison rating scale is a method to provide qualitative opinions on a value. For various problems, the scale of 1 to 9 is the best scale in expressing opinion [4]. The first thing to do is to compile a paired comparison.

Comparisons are made based on decision-making policy by assessing the importance of one element to another. Pairwise comparison process, starting from the top level hierarchy shown to select criteria, for example A1, A2 and A3. They are shown in Table 1, an example of a paired comparison matrix.

To determine the value of relative importance between elements, a scale of numbers from 1 to 9 is used, if an element is compared to itself, then it will be given a value of $i$. if the value of $i$ is compared with the value of $j$ acquire a certain value, accordingly the value of $j$ compared to the value of $i$ is the opposite.

Considerations for pairwise comparisons are synthesized to obtain the overall priority values of the elements with equation (3).

$$
w_{i}=\frac{\sqrt[n]{\Pi_{j=1}^{n} \cdot a_{i j}}}{\sum_{i=1}^{n} \sqrt[n]{\Pi_{j=1}^{n} \cdot a_{i j}}}
$$

Explanation:

$w_{i}=$ the priority weight of the $i$ element (criteria).

$a_{i j}=$ the element value in $i$ line and $j$ column.

$n=$ number of elements. 
Table 1 The Example of Pairwise Comparison Matrix [4]

\begin{tabular}{|c|c|c|c|}
\hline & A1 & A2 & A3 \\
\hline A1 & 1 & & \\
\hline A2 & & 1 & \\
\hline A3 & & & 1 \\
\hline Total & & & \\
\hline
\end{tabular}
as follows:

The step in obtaining priority values according to the above equation can be explained

1. Multiplying each element in the same row and the results are measured by the square root of the number of elements.

2. Adding all the values obtained from the root results in number 1 .

3. The value of root number 1 for each element is divided by the sum of the value of the root result number 2, then the priority weight of each element is obtained.

After synthesizing the considerations, the priority weights for each of the following elements are then obtained to measure consistency. Consistency is important to get valid results in the real world. Just like AHP, ANP measures consistency considerations with consistency ratio. The consistency ratio must be less than 0.1 . If it is more than this ratio, the matrix comparison value must be conducted again.

Steps to calculate consistency ratio, consists of:

1. Calculating the eigen value $\left(\lambda_{\max }\right)$ like equation (4).

$$
\lambda_{\max }=\sum_{j=1}^{n}\left(\sum_{i=1}^{n} a_{i j}\right) w_{j}
$$

Explanation:

$w_{j}=$ the priority weight of the $j$ element (criteria).

$a_{i j}=$ The element value in $i$ line and $j$ column.

2. Calculating the consistency index with equation (5).

Explanation:

$$
C I=\frac{\lambda_{\max }-n}{n-1}
$$

$C I=$ Consistency Index

$\lambda_{\max }=$ Eigen value

$\mathrm{n} \quad=$ Number of elements

3. Calculating the consistency ratio by equation (6).

Explanation:

$$
C R=\frac{C I}{R I}
$$

$C R=$ Consistency Ratio

$C I \quad=$ Consistency Index

RI $\quad=$ Random Index

The Random Index used can be seen on Table 2.

Table 2 Random index [6]

\begin{tabular}{|c|c|c|c|c|c|c|c|c|c|c|c|c|c|c|}
\hline$n$ & 1,2 & 3 & 4 & 5 & 6 & 7 & 8 & 9 & 10 & 11 & 12 & 13 & 14 & 15 \\
\hline$R I$ & 0,00 & 0,58 & 0,90 & 1,12 & 1,24 & 1,32 & 1,41 & 1,45 & 1,49 & 1,52 & 1,54 & 1,56 & 1,58 & 1,59 \\
\hline
\end{tabular}

\subsection{Model Analytical Network Process}

Two-way network is structural solution to problem solving that cannot be arranged using hierarchical structure. Two-way network consists of interaction and dependency between elements at the level below. The feedback structure does not have a linear shape from top to bottom, however it looks like a cycle network in each cluster of each element and can be in the form of a loop on the cluster itself [7]. This form cannot be called as a level. Feedback also has source and sink. The point of the source shows the origin of the path of interest and has never 
been the goal of the other interest path, while the sink point is the point that becomes the goal of the path of interest and has never been the origin for other purpose. Figure 2 shows the ANP network structure of the sub criteria for selecting Robusta Coffee plants on the land.

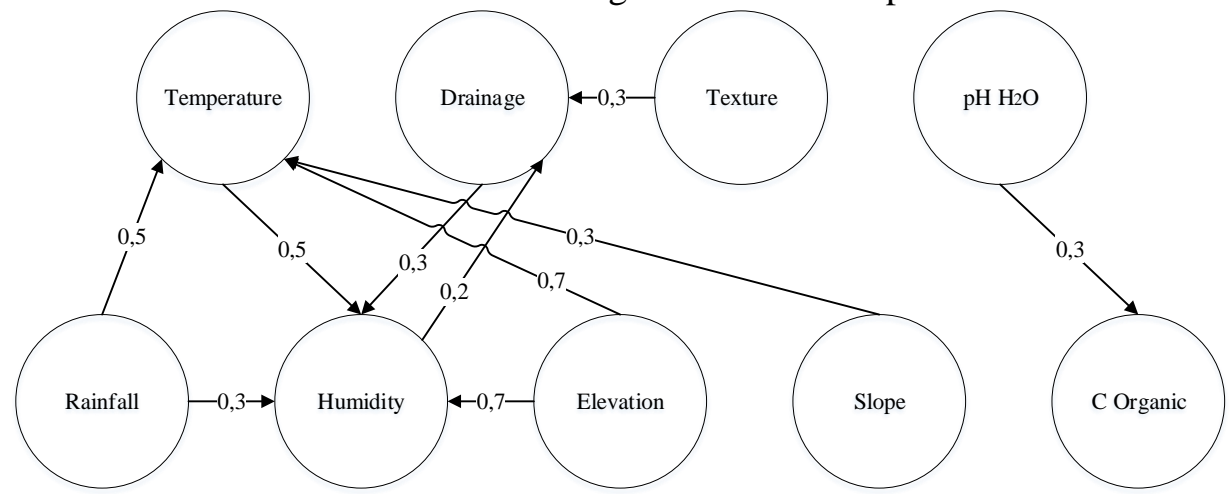

Figure 2 ANP network structure sub criteria for selecting Robusta coffee plants on land

\subsubsection{Supermatrix and Weighting}

The value of the supermatrix is given as a result of the assessment of the priority scale derived from pairwise comparison such as the AHP. The matrix is arranged to describe the flow of interest between components both in inner dependence and outer dependence. In general, the relationship of interests between elements with other elements in the network can be represented following the supermatrix. Figure 3 shows the supermatrix.

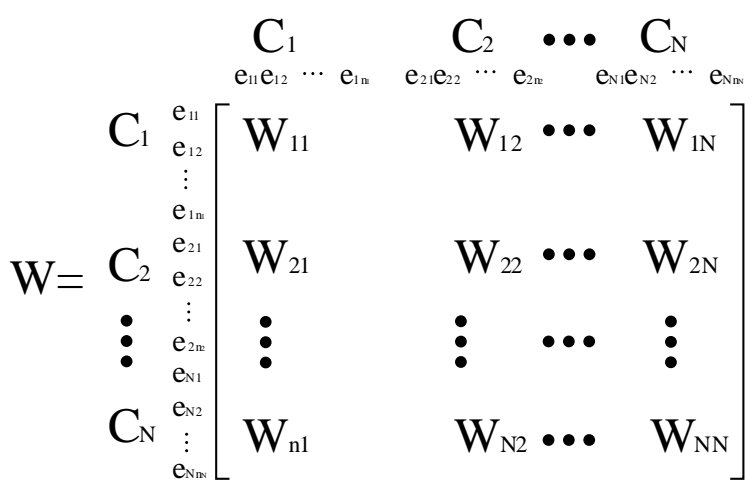

Figure 3 Supermatrix [8]

\subsubsection{ANP Steps}

[8], [9] the main steps in calculating the criteria weight with ANP are as follows:

\section{Stage 1}

Without assuming interdependence between criteria, decision makers are asked to evaluate all criteria in pairs. The response given is numerically shaped with a basis of Saaty 1 - 9. Each pair of criteria is only compared once. Reciprocal values are automatically given in opposite comparison. The results of stage 1 are calculated by equation (3).

2. Stage 2

The second stage is carried out to determine the effect of existing interdependence between evaluation criteria, namely by way of decision makers examining the influence of all criteria into other criteria using pairwise comparison. A number of paired comparisons are carried out for each criterion. Pairwise comparison is needed in order to identify the relative influence of dependency relationship between criteria. The principal normalized priority value for these matrices is calculated and displayed as a column component of the weight of the effect of interdependence on the matrix $\mathrm{B}$, where the 
value is given to criteria that have no dependence. In this study, the value given is between 0 to 1 , where the value close to 1 is the largest level of influence, and the value close to 0 has the smallest level of influence [10].

3. Stage 3

In the third stage, the results of the first and second stages of the synthesis are performed using equation (7), so that the priority weights of the interdependence kriteria can be obtained.

$$
W_{c}=B \cdot w
$$

Explanation:

$W_{c}=$ Weight of criteria with interdependence used in the process of calculating modified profile matching.

$B$ = Matrix of interdependence between criteria.

$w=$ Weight of criteria in stage 1.

\subsection{Profile Matching Model}

Profile matching method is a method that is often used as a mechanism in decision making by sharing that there is an ideal level of predictor variables that must be met by the subject under study, not the minimum level that must be met or passed. Broadly speaking, profile matching is a process of comparing the actual data values from a profile that will be assessed with the expected profile value, therefore difference in competence can be known (also called gap). The smaller the gap produced, the greater the weight of the value.

The following are some stages and formulations of calculation using the profile matching method:

1. Mapping gap value

Conducting competency gap mapping, the gap in question is the difference between profile attribute and target profile. To acquire the difference value or gap from the two profiles, equation (8) can be implemented.

$$
\text { Gap }=\text { Value Atribut }- \text { Value Target }
$$

2. Weighting

Determining the gap value weight competence. At this stage, it will determine the weight of the value of each gap value by referring to Table $\mathbf{3}$, the weight of the GAP value.

Table 3 The weight of the GAP value [4]

\begin{tabular}{|l|l|l|l|}
\hline No. & $\begin{array}{c}\text { GAP } \\
\text { Difference }\end{array}$ & $\begin{array}{c}\text { Value } \\
\text { Weight }\end{array}$ & \multicolumn{1}{c|}{ Explanation } \\
\hline 1. & 0 & 4 & Competence as needed \\
\hline 2. & 1 & 3,5 & Individual competence have an excess of 1 level \\
\hline 3. & -1 & 3 & Individual competency is less than 1 level \\
\hline 4. & 2 & 2,5 & Individual competence have an excess of 2 level \\
\hline 5. & -2 & 2 & Individual competency is less than 2 level \\
\hline 6. & 3 & 1,5 & Individual competence have an excess of 3 level \\
\hline 7. & -3 & 1 & Individual competency is less than 3 level \\
\hline
\end{tabular}

3. Core and Secondary Factor.

At this stage, it will determine the value of each aspect of the core factor and secondary factor.

a. Core factor is the most prominent aspect (competence) needed by a position which is expected to produce optimal performance.

b. Secondary factor is items other than aspects that exist on the core factor.

4. Calculation of Total Value.

Calculating the total value of all aspects based on the average value of core factor and secondary factor that have been generated with the percentage of each dactor inputted, 
i.e., the core factor given a value of $60 \%$ and the secondary factor given a value of $40 \%$, the following is equation (9) which is used to calculate the total value.

$$
N=(x) \% . N C F+(x) \% . N S F
$$

Explanation:

$N$ : Total value

$x$ : The value of percent

$N C F$ : Core factor value

$N S F$ : Secondary factor value

5. Ranking.

Determining the ranking value. The final result of the calculation process of the Profile Matching model is calculating the value of the ranking offered. To determine the rank, it can use equation (10).

Explantion:

$$
\text { Ranking }=\left(\left(x_{1}\right) \cdot N_{1}\right)+\left(\left(x_{2}\right) \cdot N_{2}\right)+\cdots+\left(\left(x_{n}\right) \cdot N_{n}\right)
$$

$x$ : The weight entered in each parameter.

$N_{l}$ : The final value of the $1^{\text {st }}$ parameter

$N_{2}$ : The final value of the $2^{\text {nd }}$ parameter

$N_{n}$ : The final value of the $\mathrm{n}$ parameter

\subsection{Modified Profile Matching Model}

Modified profile matching is a profile matching method with calculations that do not use GAP value mapping, weighting GAP values, core factors, secondary factors, and calculating total values. Calculations carried out based on the value of proximity to qualitative data and linear interpolation functions on quantitative data by weighting on the suitability class in Table 4.

Table 4 Suitability class

\begin{tabular}{|c|c|c|}
\hline Type & Suitability class & Weight \\
\hline Very Suitable & S1 & 3 \\
\hline Quite appropriate & S2 & 2 \\
\hline Appropriate marginal & S3 & 1 \\
\hline It is not in accordance with & N & 0 \\
\hline
\end{tabular}

Where in determining the score on the modified profile matching model, direct weighting is used with the suitability class for proximity values and equation (2) for linear interpolation functions. The results of the scores of the two calculations are then multiplied by the weight of the ANP and produce a ranking score with equation (11).

$$
\text { Score ranking }(j)=x_{i j} * B_{i}
$$

Explantion:

$J=$ The alternative

$X_{i j}=$ Modified profile matching score

$B i=$ ANP weight

\section{RESULTS AND DISCUSSION}

The testing of the calculation is conducted by entering the data in the form of a scale value in the paired comparison matrix by LPP experts in each criterion and sub criteria which will produce consistent AHP weight value. In the network structure model, it entered a value between 1 to 0 based on the relationship that has been established by LPP experts which can be seen in Figure 2 for the structure of relations of Arabica coffee sub criteria. It is then normalized, and the results of normalization are added to each column in each each row and the 
sum of the results are multiplied by the global weight of AHP. Hence, the output in the form of ANP weight value is obtained. Later, into the phase of calculation using the profile matching method. Entering all values of land characteristics from the 8 existing districts, subsequently, calculating profile matching score based on scoring through conformity classes with proximity values on qualitative data and linear interpolation functions on quantitative data. Afterwards, each profile matching score multiplied by each ANP weight value, so that the final value is obtained in the form of a ranking, which is then used as a recommendation for coffee plants that are suitable for the land.

\subsection{The test result}

The value of the results from the merging of the ANP method and the modified profile matching were tested with 3 stages of testing, namely as follows:

1. The first test is done by looking at the results of ranking scores between systems with manual calculations that are built using a worksheet. The results of testing the ranking scores obtained using the system and manual calculations have very similar matches. Following Table 5 shows a comparison of the results of ranking scores between the outputs of the system and from manual calculations:

Table 5 Testing between systems and manual calculations

\begin{tabular}{|l|l|l|l|l|l|l|}
\hline \multirow{2}{*}{ Sub-district } & \multicolumn{2}{|c|}{ Arabica coffee } & \multicolumn{2}{c|}{ Robusta coffee } & \multicolumn{2}{c|}{ Liberica coffee } \\
\cline { 2 - 7 } & system & manual & system & manual & system & manual \\
\hline Aikmel & 1,347 & 1,347 & 1,930 & 1,930 & 1,814 & 1,814 \\
\hline Masbagik & 1,347 & 1,347 & 1,810 & 1,810 & 1,682 & 1,682 \\
\hline $\begin{array}{l}\text { Montong } \\
\text { Gading }\end{array}$ & 1,199 & 1,199 & 1,718 & 1,718 & 1,741 & 1,741 \\
\hline Pringgasela & 1,347 & 1,347 & 1,930 & 1,930 & 1,814 & 1,814 \\
\hline Sembalun & 1,763 & 1,763 & 1,252 & 1,252 & 1,342 & 1,342 \\
\hline Sikur & 1,227 & 1,227 & 1,625 & 1,625 & 1,609 & 1,609 \\
\hline Suela & 1,143 & 1,143 & 1,715 & 1,715 & 1,622 & 1,622 \\
\hline Wanasaba & 1,227 & 1,227 & 1,745 & 1,745 & 1,741 & 1,741 \\
\hline
\end{tabular}

2. The second test is done by looking at the results of ranking between systems by combining the ANP method and modified profile matching by combining the ANP method and the unmodified matching profile. Table 6 shows the ranking results using the modified profile matching method and the unmodified profile matching.

Table 6 The ranking results of the modified PM method and the unmodified PM method

\begin{tabular}{|c|c|c|c|c|c|c|}
\hline \multirow{2}{*}{ Sub-district } & \multicolumn{3}{|c|}{ Modified Profile Matching } & \multicolumn{3}{c|}{$\begin{array}{c}\text { Unmodified Profile } \\
\text { Matching }\end{array}$} \\
\cline { 2 - 7 } & \multicolumn{3}{|c|}{ ranking } & \multicolumn{3}{c|}{ ranking } \\
\cline { 2 - 7 } & $\mathbf{1}$ & $\mathbf{2}$ & $\mathbf{3}$ & $\mathbf{1}$ & $\mathbf{2}$ & $\mathbf{3}$ \\
\hline Aikmel & Robusta & Liberica & Arabica & Robusta & Liberica & Arabica \\
\hline Masbagik & Robusta & Liberica & Arabica & Robusta & Liberica & Arabica \\
\hline Montong Gading & Liberica & Robusta & Arabica & Liberica & Robusta & Arabica \\
\hline Pringgasela & Robusta & Liberica & Arabica & Robusta & Liberica & Arabica \\
\hline Sembalun & Arabica & Liberica & Robusta & Arabica & Liberica & Robusta \\
\hline Sikur & Robusta & Liberica & Arabica & Robusta & Liberica & Arabica \\
\hline Suela & Robusta & Liberica & Arabica & Robusta & Liberica & Arabica \\
\hline Wanasaba & Robusta & Liberica & Arabica & Robusta & Liberica & Arabica \\
\hline
\end{tabular}

IJCCS Vol. 13, No. 3, July 2019: $241-250$ 
3. The third test is done by looking at the results of ranking tests of the calculations built using a merged ANP method and modified Profile Matching through inputting data from Yogyakarta LPP Polytechnic experts and employees in the NTB Province Agriculture Service in the plantation sector. In Table 7 shows the results of ranking from data from LPP Polytechnic experts and the Agriculture Office of West Nusa Tenggara Province.

4.

Table 7 Ranking results from data from LPP Polytechnic experts and the Agriculture Office of West NTB Province

\begin{tabular}{|c|c|c|c|c|c|c|}
\hline \multirow{2}{*}{ Sub-district } & \multicolumn{3}{|c|}{ LPP Polytechnic expert } & \multicolumn{2}{c|}{$\begin{array}{c}\text { Agriculture Office of West } \\
\text { NTB Province }\end{array}$} \\
\cline { 2 - 7 } & \multicolumn{3}{|c|}{ ranking } & \multicolumn{3}{c|}{ ranking } \\
\cline { 2 - 7 } & $\mathbf{1}$ & $\mathbf{2}$ & $\mathbf{3}$ & $\mathbf{1}$ & $\mathbf{2}$ & $\mathbf{3}$ \\
\hline Aikmel & Robusta & Liberica & Arabica & Robusta & Liberica & Arabica \\
\hline Masbagik & Robusta & Liberica & Arabica & Robusta & Liberica & Arabica \\
\hline Montong Gading & Liberica & Robusta & Arabica & Liberica & Robusta & Arabica \\
\hline Pringgasela & Robusta & Liberica & Arabica & Robusta & Liberica & Arabica \\
\hline Sembalun & Arabica & Liberica & Robusta & Arabica & Liberica & Robusta \\
\hline Sikur & Robusta & Liberica & Arabica & Robusta & Liberica & Arabica \\
\hline Suela & Robusta & Liberica & Arabica & Robusta & Liberica & Arabica \\
\hline Wanasaba & Robusta & Liberica & Arabica & Liberica & Robusta & Arabica \\
\hline
\end{tabular}

\subsection{The discussion of test results}

Based on the results of the three previous tests, the first test in Table 5 shows the results of the ranking score obtained using the system and the manual calculation has a very similar match. The second test in Table 6 shows that the ranking results using the modified profile matching method and the unmodified profile matching method through calculating the score based on the weight of the GAP value / profile value have the same rankin. The third test in Table 7 which shows the ranking results from data from LPP Polytechnic experts and the Agriculture Office of West NTB Province shows different results in Wanasaba sub-district for ranking 1 and rank 2 by Polytechnic experts LPP produces robusta and liberica and by the Agriculture Office of West NTB Province produces liberica and robusta .

\section{CONCLUSIONS}

Based on experiments from the research that has been carried out, the conclusions obtained are the results of tests conducted between the results of ranking scores from the system with manual calculations get results with very similar matches so that this system can be used as a system to recommend the selection of coffee plants to a land. From the recommendations generated by the system between the merging of the ANP method and profile matching modified by the ANP method and the unmodified matching profile produces the same ranking output, where in the matching profile that is not modified the mapping is done using the value gap weight. Tests carried out based on 2 input comparison scale data on the ANP method pairing comparison matrix by LPP Polytechnic experts and the Agriculture Office of West NTB Province obtained different ranking results, where in Wanasaba sub-district for ranking 1 and rank 2 by Polytechnic experts LPP produced robusta and liberika and by the Agriculture Office of West NTB Province produces liberika and robusta. 


\section{REFERENCES}

[1] D.G. Rossiter, "Land Evaluation, Dept. of Soil, Crop \& Atmospheric Sciences," College of Agriculture and Life Sciences, Cornell University, 1994.

[2] S. Ritung, K. Nugroho, A. Mulyani, and E. Suryani, "Petunjuk Teknis Evaluasi Lahan Untuk Komoditas Pertanian (Edisi Revisi)," Bogor: Balai Besar dan Pengembangan Sumberdaya Lahan Pertanian (Badan Penelitian dan Pengembangan Pertanian), 2011.

[3] E. Turban,J.E. Aronson, and T.P. Liang, "Decision Support Systems and Intelligent Systems 7th Edition," New Delhi, Prentice Hall, Inc, 2005.

[4] H. Pratiwi, "Buku Ajar Sistem Pendukung Keputusan Edisi.1, Cetakan.1," Yogyakarta: Deepublish, 2016.

[5] S.B. Sasongko, "Metode Numerik Dengan Scilab," Yogyakarta: Andi Offset, 2010.

[6] T.L. Saaty, "Decision Making with the Analytic Hierarchy Process," Int J Service Sciences, vol. 1, no. 1, pp. 83-98, 2008 [Online].

[7] A.S. Rusydiana, and A. Devi, "Analytic Network Process: Pengantar Teori dan Aplikasi,” Bogor: SMART Publishing, 2013.

[8] H.J. Shyur, "COTS evaluation using modified TOPSIS and ANP," Applied Mathematics and Computation, vol. 177, no. 1, pp. 251-259, June. 2016 [Online]. Available: https://www.sciencedirect.com/science/article/abs/pii/S0096300305009070.

[9] M. Dagdeviren, "A hybrid multi-criteria decision-making model for personnel selection in manufacturing systems," Journal Of Intelligent Manufacturing, vol. 21, no. 4, pp. 451460, Nov. 2008 [Online]. Available: https://link.springer.com/article/10.1007/s10845008-0200-7.

[10] W.J.L. Adams and D.L. Saaty, "Method and system for analytic network process (ANP) total influence analysis," Arlington: Decision Lens Inc, 2011. 